\title{
Oxidative stability, structural and textural properties of margarine enriched with Moringa oleifera leaves extract
}

\author{
Sara Ouahrani ${ }^{1}$, Daylan A. Tzompa-Sosa ${ }^{2}$, Koen Dewettinck ${ }^{2}$, and Farid Zaidi ${ }^{1}$ \\ ${ }^{1}$ University of Bejaia \\ ${ }^{2}$ Ghent University Faculty of Bioscience Engineering
}

May 28, 2020

\begin{abstract}
Consumer's demand for more natural food formulations has driven the development of alternative food additives. This study falls within this challenge through valorisation of Moringa oleifera leaves grown in Algeria as a possible natural food additive. The application of Algerian Moringa oleifera leaves extract (MOLE) was evaluated as a substitute of vitamin E in margarine at various addition levels $(400 \mathrm{ppm}, 600 \mathrm{ppm}$ and $800 \mathrm{ppm})$. The impact on margarine quality attributes was studied, namely oxidative stability, structural and textural structural properties. It was shown that addition of MOLE to margarine increased resistance towards oxidation, showing a higher antioxidant capacity as compared to vitamin E. Moreover, MOLE formulated in margarine served as an emulsifier decreasing water droplet size, which is desirable from a microbiological viewpoint. These observed effects can have a positive impact on margarine's shelf life. Furthermore, addition of MOLE leads to the formation of smaller fat crystals, resulting in a different microstructure. MOLE also increased the hardness of margarine by altering the crystallization process. Practical applications: MOLE represents a natural, food-grade additive that prevents lipid oxidation. It is a food ingredient that can contribute positively to margarine quality and to the development of clean-label food products.
\end{abstract}

\section{Hosted file}

06052020_article a soumettre_JA0CS.docx available at https://authorea.com/users/327387/ articles/454970-oxidative-stability-structural-and-textural-properties-of-margarineenriched-with-moringa-oleifera-leaves-extract

\section{Hosted file}

Figures_moringa oleifera.docx available at https://authorea.com/users/327387/articles/454970oxidative-stability-structural-and-textural-properties-of-margarine-enriched-withmoringa-oleifera-leaves-extract 